\title{
Sektor Informal: Suatu Mozaik Kemiskinan Kota dan Dístorsi Kebijakan Pembangunan
}

\author{
、 Oleh : Arif Hartono
}

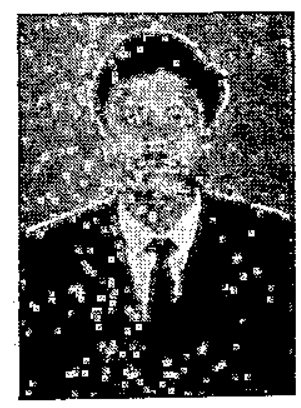

Arif Hartono, dilahirkan di Klaten, 28 Oktober 1969. Setelah menyelesaikan studi srata satunya di Fakultas Ekonomi Ull pada tahun 1992, ia mengabdikan diripada almamaternya mulai tahun 1993. Selain sebagai staf pengajar tetap FE UII, ia juga menjabat sebagai staff $P D$ IIIFE UIitahun 1994 - 1995 dan dilanjutkan padaperiode 'kepengurusan 1995 - 1998.' Disamping itu ia juga aktif dalam kegiatan jurnalistik sebagai Sekretaris Redaksi majalah Unisia dan juga duduk sebagai Dewan Redaksi majalah Al-Islamiah.

\section{Pengántar}

Ciri khas dari proses perubahan di banyaknegara sedang berkembang, ditandai antara lain, ketidakmerataan pertumbuhan yang semakin lebar. ${ }^{1}$ Ketidakmerataan ini tidak hanya menandai hubungan antara' lapisan dan kelompok-kelompok ekonomi, tapi juga termanifestasikan dalam hubungan kota-desa dan sektor-sektor ekonomi.

Sektorindustri yang sampai sekarang diyakini sebagai "panglima pembangunan ekonomi" yang sangat tangguh, dalam realitanya juga banyak menimbulkan ekses negatif yang cukup komplek. Industrialisasi. yang dikembangkan dengan tujuan untuk mensejahterakan masyarakat, ${ }^{2}$ yang salah satunya adalah kemampuannya-dalam menampung aliran tenaga kerja, temyata belum mampu membereskan permasalahan pengangguran yang kronis. $^{3}$

Kebijakan industrialisasi yang mengabdi kepada pertumbuhan ekonomi, dalam situasi melimpah ruahnya penawaran tenaga kerja, jelas tidak berfungsi dalam usaha penyerapan tenaga kerja yang ada. Lebih dari itu, ada kecenderungan bahwa berbagai jenis industri kecil dan kerajinan tersaingi. secara langsung, dan sebagian

1) Lebih jauh tentang paradigma perkembangan dapat dilihat antara lain Ian Roxborough, Tcori-teori Keterbelakangan, LP3ES, Jakarta 1990

2) Sumitro Djojohadikusumo, Perdagangan dan Industri Dalam Pembangunan, LP3ES, Jakarta, 1987 hal $51-78$

3) Lihat juga Arif Hartono, Gugatan Káum BuruhTerhadap Ketimpangan dalam Industri, Jurnal Ekonomi TH. I Vol.3 Juni 1994, FE UII, Yogyakarta hal $52-58$ 
terpaksa gulung tikar. Dalam aspek yang lain, mekanisasi pertanian yang dijalankan telah pula menghempaskan ke luar banyak tenaga kerja; termasuk wanita, dari tempat mereka selama ini hidup dan mencari nafkah.

Perbedaantingkat pertumbuhan yaing mencolok antara desa dan kota -- sementara itu sektor pertanian dirasaḱan kurang memberi harapan lagi bagi masa depan -menjadikan masyarakat pedesaan terpikat untuk "hijrah" ke kota guna berburu kesempatan kerja yang lebih menjanjikan hari esok, maka terjadilah aliran gelombang tenaga kerja yang membludak menuju perkotaan.

Mereka yang terutama temempas ke luar sektor pertanian dan tanpa penyerapān di dunia.industri yang lebih padat modal, kemudian berkelana diantara keduanya. Mereka ini, para pedagang kaki lima, pedagang kecil, gelandangan, pemungut sampah, pembantu rumah tangga dan sebagainya, membentuk laskar raksasa yang bemama sektor informal. ${ }^{4}$ Menurit Keith Hart fenomena kemunculan "ekonomi bawah tanah (underground economics)" yang tumbuh suburdi perkotaan ini sebagai implikasi dari bias perkembangan ekonomi perkotaan yang kian terbelah.

Kajian terhadap ketimpangan desakota serta kontroversi terhadap keberadaan "ekonomi jalänan" menjadi sangat menarik untuk dicermati dikarenakan permasalahan ini sudah sedemikian kronis dan telah menelan korban "kaum papa" yang tidak sedikit jumlahnya. Para laskar mandiri ini harus menelan pil pahit sebagai akibat dari penanganan masalah kemiskinan dan ekonomi informal perkotaan khususnya yang belum beranjak dari pola kebijakan ortodok: ușir, dan gusur demi kebersihan, keamanan dan kenyamanan kota. ${ }^{5}$ Meskipun harus diakui terdapat beberapa kebijakan yang terpuji, ${ }^{6}$ tetapi masalah kemiskinan dan informalisasi yang berkembang masih jauh dari jangkauan kebijakan yang sering sangat bersifat mikro.

\section{Potret Kemiskinan Kota}

Distorsi paradigmakemiskinan telah menjadikan pembahasan - tentang kemiskinan kota tidak -sepopuler kajian tentang kemiskinan desa. Fenomena ini muncul dilatarbelakangi oleh adanya realita bahwa sebágian besar masyarakat dunia ketiga -- termasuk didalamnya Indonesia- tinggal di daerah pedesaan, sehingga secara kuantitatif sebagian besar kemiskinan pun ada di pedesaan.

Distorsi ini tampaknya semakin menggejala dengan digulirkannya Inpres Desa Tertinggal (IDT) ${ }^{7}$ bukan Inpres

4) Kajian lebih jauh mengenai masalah industrial isasi dalam kaitannya dengan pembangunan antara lain Sritua Arief dan Adi Sasono, Indonesia : Ketergantungan dan Keterbelakangan, LSP, Jakarta, 1981.

5) Kasus-kasus penggusuran becak, garukan pedagang `asongan dan kakilimạ, penyempitan wilayah operasi bajaj dan ojek serta penggusuran pemukiman kaum pinggiran adalah refleksi real dari pola kebijakan yang sangat mikro dan parsialistik.

6) Antara lain dapat dilihat dari gerakan kali bersih, upaya pembangunan. lingkungan kumuh menjadi perüusahaan yang diprioritaskan untuk warga marginal tersebut serta beberapa upaya pembinaan usaha pembinaan dalam berbagai model patronase.

7) Istilah desa tertinggal digunakan karena dirasakan lebih halus (tetapi pada esensinya sama), . dan secara psikologis mempunyai keuntungan yang lebih, dalam upaya pengentāsannya mengingat-setting budaya ketimuran sangat leka! dengan masyarakat Indonesia, terlebih yang ada di pedesaan. 
Daerah Tertinggal -- sebagai upaya terapi terhadap kondisi kemiskinan yang telah kronis. Walaupun dalam operasionalisasinya IDT tidak meninggalkan kelurahan-kelurahan miskin yang ada di perkotaan, tetapi paling tidak penggunaan istilah desa tertinggal sempat membuat "iri" para pemerhati dan masyarakat kota tertinggal/kemiskinan kota.

Tanpa menafikkan arti penting pengentasan desa tertinggal, ${ }^{8}$ realita lain yang tidak bisa dipungkiri adalah bahwa ternyata perkotaan pun menyimpan masyarakat miskin yang tidak kecil jumlahnya. Hal ini nampak jelas páda banyaknya perkampungan-perkampungan kumuh, gubug-gubug tempel, pengemispengemis jalanan, pemulung sampah atau bahkan komplek lokalisasi WTS yang hampir dapat ditemui di setiap kota yang ada di Indonesia. ${ }^{9}$

Sketsa di atas memberikan gambaran bahwa sebenamya kemiskinan tidak hänya ada di pedesaan, namun kemiskinan kota juga merupakan permasalahan yang serius. Jumlah masyarakat golongan miskin di perkotaan cukup besar. Data dari Bappenas sebagaimana terlihat pada tabel 1 menunjukkan bahwa, pada tahun 1976 ditemukan $38,79 \%$ atau 10 juta penduduk kota dalam keadaan miskin (pada tahun yang sama penduduk desa yang miskin sebesar $40,37 \%=44,2$ juta jiwa), sementara pada tahun 1993 di perkotaanmasih terdapat $13,45 \%$ atau 8,7 juta penduduk yang miskin (di pedesaan $13,79 \%=17,2$ juta jiwa). Data ini menunjukkan bahwa selama 17 tahun kemiskinan di perkoțaan hanya terjadi penurunan sebesar $13 \%$, sedangkan di pedesaan penurunan jumlah orang miskin sebesar $61,09 \%$. Ini berarti penurunan jumlah kemiskinan di kota jauh lebih lambat dibanding yang terjadi di pedesaan.

Tabél 1:

Batas Persentase dan Jumlah Penduduk Miskin 1976 - 1993

\begin{tabular}{|c|c|c|c|c|c|c|c|c|}
\hline \multirow{2}{*}{ Tanum } & \multicolumn{2}{|c|}{ 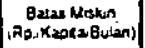 } & \multicolumn{3}{|c|}{ Prosemesso Ponduchi Mosten } & \multicolumn{3}{|c|}{ 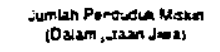 } \\
\hline & $K \alpha_{0}$ & Podosen & $\operatorname{kos}$ & ons & Kas-Onen & Ken & Des & Kotaratesa \\
\hline 1976 & 4522 & 2.849 & 39.79 & 40.37 & 40.08 & 10.8 & $\mu ?$ & 54.2 \\
\hline 1978 & 2.969 & $2.98 t$ & $30.8+$ & 33.39 & 33.31 & B.3 & 397 & 47.2 \\
\hline 1980 & $6.23 t$ & 4.49 & 29.08 & 28.42 & 28.56 & 9.5 & 32.3 & 423 \\
\hline 1981 & 9.7 & 5.87 & 28.06 & 26.85 & 26.35 & 9.3 & 313 & 20.6 \\
\hline 1984 & 13.731 & 7.746 & 7.746 & 23.14 & 21.64 & 9.3 & $25^{*}$ & 35.0 \\
\hline 1987 & 17.381 & 10.294 & 10.294 & 20.14 & 17.42 & 9.7 & 203 & 30.0 \\
\hline 1990 & 29.614 & 13.295 & 13.295 & 16.75 & 15.08 & 9,4 & 173 & 2.2 \\
\hline 1993 & 27905 & 18.244 & 13.254 & 13.45 & 13.57 & $9:$ & 172 & 25.9 \\
\hline
\end{tabular}

Sumber : Mubyarto, 1994

8) Pada dasamya kemiskinan desa dan kota mempunyai keterkaitan yang sangat erat, bahkan tidak dapat dipisahkan. Karena dari berbagai teori yang ada serta didukung banyak penelitian ditemukan bahwa kemiskinan di pedesaan merupakan faktor pendorong utama terjadinya migrasi penduduk dari desa ke kota.

9) Lihat antara lain John. L. Taylor, Kampung-kampung Miskin dan Tempat Pengelompokan Penghuni Liar di Kota-kota Asia Tenggara, dalam Parsudi Suparlan '(editor). Kemișinan di Perkotaan, Yayasan Obor Indonesia, Jakarta, 1993 hal 90 - 98 
Kemiskinan di perkotaan menupakan masalah yang laten dan kompleks yang implikasi sosial dan kebudayaannya bukan hanya melibatkan dan mewujudkan berbagai masalah sosial yang ada di. kota yang bersangkutan saja ataupun hanya menjadi masalah bagi orang miskin di kota tersebut, tetapi melibatkan juga masalahmasalah yang ada di pedesaan dan dikotakota lainnya dan melibátkan juga golongangolongan sosial lainnya yang ada di perkotaan maupun di pedesaan baik secara langsung maupun tidak langsung: Ketidakmampuan dalam mengangkat masyarakat miskin di perkotaan merupakan masalah yang gawat, karenà akan sangat. dimungkinkan munculnya proses pemiskinan baru sebagai dampak dari urbanisasi yang masih sangat sulit dibendung sedangkan mereka belum mendapat penanganan yang memadai. ${ }^{10}$.'

Telaah kemiskinan kota semakin mempunyai arti penting ketika ditemukan kenyataan bahwa terjadi kenaikan pendapatan rata-rata golongan kaya perkotaan lebih cepat dibanding golongan miskin, sementara di pedesaan sudah terjadi . percepatan kenaikan pendapatan rata-rata yang lebih baik bagi penduduk miskin dibanding dengan golongan kaya. ${ }^{11}$.

\section{Migrasi Desa - Kota: Telaah tentang Motivasi dan Informalisasi Sektor Ekonomi}

Padahakekatnya mobilitaspenduduk merupakan refleksi perbedaan pertumbuhan danketidakmerataan fasilitaspembangunan antara satu daerah dengan daerah lain. Orang-orang dari daerah yang fasilitas sembangunannya kurang. akan bergerak menuju kedaerah yang mempunyai fasilitas pembangunan yang lebih baik. Demikian jugaterjadi gerakmobilitas penduduk antara desa dan kotadidorong karena pertumbuhan desa masih ketinggalan daripada pertumbuhan kota. Ditambah lagi dengan kenyataan bahwa fasilitas pembangunan kota jauh lebih lengkap daripada fasilitas pembangunan desa.

Sekalipun demikian, tingkat arus gerak penduduk tersebut tidak terlepäs dari karakteristik sosial ekonomi dan sosial budaya daerah yang bersangkutan. Terbatasnya sumberdayat alam dan kebutuhan ekonomi akan menjadi faktor pendorong bagi orang-orang untuk pergi dari daerahnya. Tetapi dipihak lain, normà sosial dalam kehidupan masyarakat setempat bisa menjadi salah satu alasan untuk tidak pergi meninggalkan desanya. ${ }^{12}$

Gejala mobilitas penduduk (tenaga kerja) dari desa ke kota di sału pihak gejala ini merupakankomponen dari pertumbuhan perkotaan (uiban growth), di pihak lain menunjukkan adanya masalah-masalah sosial ekonomi di daerah yang cukup memprihatinkan. ${ }^{13}$

10) Lihat Edy Suandi Hamid. Penanggulangan Kemiskinan di Indonesia (Catatan program IDI dan Kemiskinan kota), Unisia, UII, Yogyakarta, No. 21, 1994, Hal 88 -94

11) Lihat Parsudi Suparlan (editor), Kemiskinan di Perkotaan, Yayasan Obor Indonesia, Jakarta, 1993, hal XV

12)Asep Djaja Saefulahı, Mobilitas Penduduk dan Perubahan di Pedesaan. Prisma. Jakarta : No. 7. 1994, hal $35-47$

13) Kartini Syahrir, Migrasi Tukang Bangunan : Beberapa Fakıor Pendorong, Prisına, (5), hal 47 -60 lihat juga Charles Adam, Pertambahan Penduduk dan Peryerbuan Daerah Kota, dalam Parsudi Suparlan (Penyunting) Op. Cit hal. 59 - 74. 
Dalam rangka menjelaskan niat bermigrasi, beberapa teori telah diperkenalkan antara lain: (1) "stressthreshold model" atau lebih terkenal dengan "place utility model", "residential satisfaction model" atau "residential prefrence model" (2) "The human capital approach" (3) "contextual analysis" dan (4) "Value expectancy model". Kombinasi atau integrasi scmua tcori tersebut telah dibcberkan dalam model "place-utility and behavior intentions". 14

Ide dasar dari stress-threshold model adalah bahwa individu merupakan makhluk rasional yang mampu memilih alternatif terbaik dengan membandingkan untung dan rugi. Individu biasanya membandingkan tempat. tinggal yang ada dan yang diharapkan berdasarkan pertimbangan untung dan rúgi. Kalau penilaian terhadap tempat tinggal sekarang negatif atau kurang menguntungkan, maka usaha mencari tempat tinggal yang baru harus segera direalisasikan.

Model human capital pada prinsipnya didasarkan atas teori pembuatan keputusan individual, dengan menekankan aspek investasi dalam rangka peningkatan produktivitas manusia. Dalam model ini niat bermigrasi lebih ditentukan usaha mencari kesempatan kerja dan pendapatan yang lebih baik. Migrasi dianggap sebagai suatu bentuk investasi individu, yang diputuskan setelah yang bersangkutan terlibat dalam kalkulasi biaya dan manfaat. Model ini lebih lanjut dikembangkan.oleh Todaro, bahwa keputusan bermigrasi merupakan respons terhadap harapan tentang penghasilan yang akan diperoleh di kota dibandingkan dengan yang diterimanya di pedesaan, dan kemingkinan memperoleh pekerjaan (Push-full factor theory). ${ }^{\text {is }}$ Sektor modem/fonmal dianggap sebagai daya tarik utama terhadap keputusan bermigrasi karena penghasilan yang diperoleh di sektor tersebut lebih tinggi. sementara sektor informal dianggap sebagai "holding tank" bagi migran yang belum sempat tertampung di sektor formal. Pemikiran tersebut kemudian direvisi olch beberapa ahli. Cole dan Sanders melihat bahwa teori yang dilontarkan Todaro hanya khusus berlaku bagi para individu yang memiliki aspek human capiral seperti pendidikan. Padahal, dalam kenyataannya banyak yang tidak memiliki aspek tersebut tetap pindah ke kota, karena daya tarik sektor informal.

Analisis kontekstual memusatkan perhatiannya pada pengaruh latar belakang struktural. Faktor-faktor dan situasi ekstemal makro harus dipentimbangkan karena faktor-faktor tersebut dapat berfungsi sebagai pendorong atau sebaliknya sebagai penghambat dalam pengambilankeputusan bermigrasi. Faktorfaktor tersebut meliputi karakteristik daerah-daerah asal dan tujuan, kesempatan kerja, tingkat upah, tanah dan sistem pemilikannya, ikatan keluarga, sistem warisan, jaringan transportasi dan komunikasi, dan akses terhadap berbagai fasilitas dan pelayanan, faktor iklim, program pemerintah dan sebagainya.

Fokus utama dari model Value ecpectancy mempelajari hubungan antara

14) Yeremian T. Keban, Studi Niat Bernigrasi di Tiga Kota, Prisı̀na, Jakarta : No. 7. 1994, hal 17 - 33

15) Lihat Michael Todaro, Pembangunąn Ekonomi Dunia Katiga, Erlangga, Jakarta. 
sikap, nilai persepsi dan niat bermigrasi. Menurut model ini, nial bermigrasi dipengaruhi oleh berbagai jenis nilai dan harapan untuk memperoleh nilai-nilai tersebut yang terdiri dari kekayaan, status, kemandirian affiliasi dan moralitas.

Model integratif mengasumsikan bahwa ${ }^{2}$ niat bermigrasi secara langsung dipengaruhi oleh tiga faktor yaitu persepsi tentang place utility, latar belakang pribadi dan struktural. Persepsi tentang place utility merupakan variabel intervening antara latar belakang struktural dan individual, dengan niat bermigrasi.

Kemiskinan, perbedaan tingkat upah dan kesempatan kerja desa dan kota telah menimbulkan gelombang migrasi menuju perkotaan. Meningkatnya angkatan kerja secara bombatis (baby boom) di pedesaan tidak dapat tertampung dalam dinamika ekonomi pedesaan yang belum beragam menyebabkan mereka meṇilih migrasi ke kota, baik melalui migrasi permanen maupun migrāsi sementara. Migrasi prematur. ini tidak mungkin tertàmpung sektor formal yang menuntut adanya keahlian dan atau pendidikan yang relatif tinggi. Sebagai alternatif -- walaupun merupakan pilihan yang terpaksa -- mereka akhimya larut dalam dinamika kehidupan sektor informal.

Pendekatan Neoklasik dari Lewis maupun Ranis-Fei yang mendasarkan pada asumsi bahwa transformasi ketenagakerjaan dari sektor pertanian menuju sektor industri merupakan suatu proses yang kontinum menjadi tidak relevan lagi dalam konteks Indonesia, karena proses industrialisasi yang terjadi tidak diikuti oleh tingkat penyerapan tenaga kerja yang memadai.

Menurut prediksi model linier kerangka model Ranis-Fei-Lewis fenomena sektor informal akan tuntas pada akhir dekade 1990-an dengan berbagai syarat bahwasektorindustribisamenyerap tenaga kerja dengan pertumbuhan penyerapan setinggi $5,2 \%$. Pada táhun 1999 diperkirakan tidak ada lagi tenaga kerja berlebihaǹ (labour surplus) karena industri sektor telah berhasil menyerap semua kelebihan tenaga kerja yang terlempar dari . sektor pertanian sebagaimana tampak pada tabel berikut.

Tabel 2:

Angkatan Kerja di Indonesia Tahun 1974 - 1999

Menggunakan Model Ranis - Fei

\begin{tabular}{|c|c|c|c|c|c|c|c|}
\hline Tehen & 1974 & ${ }_{3}^{1979}$ & $\begin{array}{c}1988 \\
10\end{array}$ & $\begin{array}{c}1989 \\
15\end{array}$ & $\begin{array}{l}1894 \\
20\end{array}$ & $\begin{array}{c}1959 \\
29\end{array}$ & $\begin{array}{c}\text { Pentumbitian } \\
\qquad|x|\end{array}$ \\
\hline 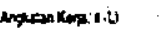 & -100.0 & 452 & 512 & 97.9 & 6.5 & '72: & 25 \\
\hline 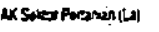 & 200 & zal & 3 & 23.3 & 23. & $21:$ & - \\
\hline 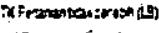 & 178 & 17.1 & 126 & 94 & 23. & $2 !:$ & 0.92 \\
\hline 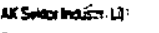 & 150 & to.t & 249 & 326 & 41.녀 & 32: & 52 \\
\hline 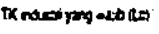 & 22.0 & 3.1 & 226 & 28 & s. & 52.3 & 35 \\
\hline 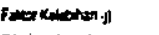 & $02:$ & 0.13 & 0.15 & 21 & 0.63 & $0:$ & $\cdot$ \\
\hline 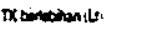 & Q. & to. & $\because 3$ & 9.8 & 13 & $0:$ & : \\
\hline
\end{tabular}

Sumber : Bruce Glassbumer dan Aditya wan Chandra, Teori dan Kebijakan ekono mi Makro. LP3ES, Jakarta, 1979, hal. $189-191$.

Model ekonomi-Ranis-Fei tersebut . lebih banyak mempertimbangkan faktorfaktor ekonomi yang rasional dengan anggapan bahwa proses komersialisasi sektorpertanian dan industrialisasiberjalan secara otomatis tanpa pengaruh kelembagaan-kelembagaan sosial, budaya dan politik. Dalam kenyataan, faktor-faktor tersebut merupakan pengaruh nyata terhadap perkembangan dan proses transformasi tenaga kerja di Indonesia. Masalah kebijaksanaan pemerintah pun 
sesungguhnya merupakan explanatory variabel yang penting dalam menerangkan masalah ketenaga kerjaan dan fenomena sektor informal sebagai penampung tenaga kerja yang potensial.

\section{Dualisme Ekonomi: Kajian Ringkas} tentang Fragmentasi Sektor Ekonomi

Perubahan-perubahan mendasar yang terjadi di pedesaan selama beberapa dekade terakhir ' menghasilkan perekonomian kota yang berwajah ganda. Pada satu sisi perckonomian kotamendapat. sentuhan dinamika ekonomi global disisi lain struktur ekonomi rakyat yang rapuh di pedesaan tertranplantasi ke kota.

Teori ekonomi ganda (dualistic economic theory $)^{16}$ yang dikembangkan J.H. Bocke meninjau pertentangan antara desa. timur, prakapitalisme dandilain pihak kota, barat,kapitalisme dan apa ciri-ciri hubungan ekonomi diantara kelompok-kelompok dari dunia itu. Inti teori ekonomi ganda menyatakan bahwa sifat sosiàl ganda adalah pertarungan antara sistem sosial impor dari luarmelawan sistem sosial asli yang bergaya tersendiri.

Dalam masyarakat ganda, salah satu dari sistem-sistem sosial yang menonjol, biasanya yang termaju, diimpor dari luar dan hidup dalam lingkungan yang baru tanpa berhasil menyisihkan atau menyerap sistem sosial lain yang telah lama tumbuh disitu, maka disini hadir sistem yang dualistisdan pluralistis. Dalam sistem sosial dan ekonomi yang dualistis ini terdapat karakteristik keterpisahan dari suatu sistem menjadi dua bagian (tradisional-modem), yang berinteraksi secara tidak seimbang dan komplek sifatnya.

Sementara itu, Michael Todaro menerangkan eksistensi dualisme dengan unsur-unsur sebagai berikut:

1. Dualisme merupakan kondisi tatanan yang berbeda dimana yang kuat dan yang lemah dapat saling terkait keberadaannya dalam ruang dan waktu yang sama.

2. Ko-eksistensi kedua tatanan terscbut bersifat kronis dan bukan merupakan tanda adanya transisi. Keadaan ini menupakan fenomena yang akan hilang karena waktu. Kesenjangan antara yang kuat dan yang lemah cenderung langsung karena tatanan dan kelembagaan masing-masing berbeda.

3. Derajat kesenjangan superioritas dan inferiorițas terbukti tidak semakin rendah, bahkan ada tendensi kesenjangan yang cenderung meningkat.

4. Interrelasi antara unsur yang kuat dan yang lemah tidak membuat yang kuat mampu menarik yang lemah. Dalam kenyataan, perkembangan yang kuat justeru menekan perkembangan yang lemah.

\section{Potensi Ekonomi Sektor Informal}

Dalam mengkaji masalah potensi yang dimiliki sektor informal, terdapat

16) Teori ekonomi ganda dapat ditelusuri dari J.H. Boeke, Economic Policy of Dual societes as Exemplefied By Indonesia, H.D. Tjeeenk Willink \& Zoon N.V. Haarlán, 1953, atau dalaın terjemabaan ringkas J.H. Booke. Meemperkenalkan Teori Ekonomi Ganda, dalam Sajogyo (penyunting). Bunga Rampai Perekonomian Desa, Yayasan Obor Indonesia \& Yayasan Agro Ekonomika, 1982, hal 1-38. Sedangkan untuk keperluan praktis telaah sektor informal lihat, Didik J. Rachbini, ekonomi informal perkotaan hal. 18 - 39, juga dalam Hidayat, Sektor Informal dalam struktur Ekonomi Indonesia , LSP Jakarta, 1980. 
perbedaan yang sangat kontras di kalangan para ahli yang terbagi dalam dua kutub besar, yaitu golongan transisi dan golongan struktural. ${ }^{17}$

Pendapat lama atau golongan transisi menganggap bahwa eksistensi sektor informal hanya sementara, dan akan hilang di kemudian hari bila pembangunan ekonomi telah berjalan mantap. Teori ini menganggap sektor informal sebagai kegiatan yang tidak produktif karena bersifat stagnant dan sementara. Golongan ini menolak dengan tegas tesis yang menyatakan bahwa hambatan yang mengekang laju pertumbuhan sektor informal datang dari pemerintah sebagai akibat dari terlalu besamya perhatian pemerintah untuk menumbuhkan sektor formal. ${ }^{18}$ Implikasi pandangan golongan ini ada dua: Pertama, bahwa tidak ada gunanya memisahkan sektor kota menjadi sektor formal dan sektor informal; Kedua, pada suatu saat kegiatan sektor informal akan mengerut dan menghilang setelah kesempatan kerja di sektor formal meluas.

Sementara itu golongan struktural melihat bahwa kemunculan sektorinformal sebagai dampak dari adanya hambatan struktutal dalam pembangunan yang bersumber dari: (1) strategi pembangunan yang menimbulkan berbagai distorsi dalam. pasar kerja/barang/jasa/uang yang cenderung menganaktirikan sektorinformal demi sektor formal; (2) struktur pasardunia yang merupakan kegiatan produksi yang padat karya di dunia ketiga; (3) kepadatan penduduk di daerah pedesaan yang relatif tinggi sehingga pekerjaan di sektor pertanian kian mengecil.

Paradoks dengan golongan transisi, golongan struktural justeru menilai bahwa sektor informal sebagai sesuatu yang dinamik, efisien danmenguntunǵkan secara ekonomik. Pelaku-pelakunya mempunyai potensi. kewiraswastaan yang kreatif. Menurut golongan ini, kegiatan yang tidak efisien dan kecilnya skala kegiatan sebagai dampak dari kebijakan menganak-emaskän sektor formal. Pandangan ini membawa implikasi: Pertama, jurang pemisah antara kedua sektor di daerah perkotaan dapat diperkecil kalau sumber-sumber dialokasikan secara lebih merata dan proteksi terhadap sektor formal dapat dikurangi dan dialihkan kepada sektor informal yang selama ini tertinggal dan ditambah lagi harus menyerap kerawanan sosial akibat penggusuran yang tersamar maupun terbuka, karena strategi industrialisasi yang dipilih; Kedua, bahwa perlu diupayakan adanya suatu kaitan baru vang dapat menyatukan kedua sektor yang seiama ini terpisah secara dikotomis.

\section{Problema Mendasar Sektor Informal dan Alternatif Kebijakan}

Studi mengenai kemiskinán dan sektor informal semakin terasa diperlukan karena para pelakunya di sektor ini semakin tidak mendapat tempat yang tepat dalam konteks totalitas 'kebijakan pemerintah. Masalah keterbelakangan sering dikaitkan tidak saja dengan masalah kelemahan intemal mereka yang terlibat di sektor in-

17) Adi Sasono, Pembinaan Sektor Informasi : Koperasi Sebagai Pelihan Kelembgaan, dalam Sri Edi Swasono (editor), Sistem Ekonomi dan Demokrasi Ekonomi, UI Press, 1985, hal 247 - 257

18) Lihat kembali "Push- pull Theory" nya Todaro yang kemudian disempurnakan oleh banyak ahli antara lain Cole, Sanders serta Temple dan juga Suharso dkk. 
formal, tetapi juga dikaitkan dengan masalah ekstemal mercka yang sifatnya struktural. Masalah struktural seperti ini nampak lebih dominan sebagai akar masalah kondisi keterbelakangan di negaranegara sedang berkembang.

Di negara-negara sedang berkembang -- termasuk Indonesia -masalah mendasar yang bersifat struktural, dirumuskan sebagai berikut : ${ }^{19}$

1. Makin memburuknya perbandingan antara luas tanah dengan jumlah penduduk, serta memburuknya bentuk pola pemilikan atas tanah

2. Meningkatnya baik jènis pengangguran yang terselubung maupun yang terbuka serta berlakunya upah yang rendah. Selain itu, juga meningkatnya jumlah kaum ploretariat di kalangari petani

3. Semakin kuatnya kekuasaan birokrasi negara yang bersifat nepotistik dan feodal, serta makin luasnya korupsi dalam birokrasi

4. Membesarnya kekuasaan golongan minoritastermasukorang asing dibidang ekonomi khususnya di sektor perdagangan dan investasi

5. Adanya dualisme sosial, ekonomi dan teknologi.

Dalam kondisi tersebut di atas, penyelesaian kemiskinan di perkotaan tidak dapat hanya dengan mengandalkan rembesan/tetesan dari kebijakan makro dan program pembangunan yang hanya mengabdi pada pertumbuhan. Pemerintah dan para pelaku ekonomi itu sendiri perlu memperhatikannasibgolongan miskin ini. ${ }^{20}$

Masalah yang fundamental yang menjadi penyebab sulitnya berkembang sektor informal ialah: Pertama, sikap pemerintah dạn pengusaha besar Indonesia yang dingin terhadap persoalan itu. Kedua, sektor informal belum mempunyai "nilai jual" sebagai jaminan kredit bank (termasuk Bank Dunia).Ketiga, perlakuan pemerintah terhadap banyak usaha sektor informal di berbagai kota, yang tercermin dalam berbagai gerakan "razia". Ribuan gerobak, becak dan bungkusan dirazia tanpa proseduŕ hukum karena mereka dituduh melanggar hukum. Keempat, bisa juga karena pengaruh mazhab pemikiran ekonomi dan yang Kelima, masalah-masalah sektor informal tidak mendapat perhatian dan tidak mendapat dukungan politis oleh karena sampai dengan dekade 1970-an masih terasa adanya sindron politis ekonomi berskala kecil. Kalau membela yang kecil-kecil dan melarat akan dianggap miring, membela kaum proletar atau kaum marheinis. ${ }^{21}$

Berbagai pénelitian sektor informal yang dilakukan di Indonesia adalah upaya menjelaskan fenomena interaksi serta mengenali sosok ekonomi informal telah menghasilkan sebelas ciri pokok yang bersifat kualitatif: ${ }^{22}$

19) Dorojatun Kuntjorojakti' (editor) . Kemiskinan di Indonesia, Yayasan Obor Indonesia, Jakarta, 1986, hal 1-32

20) Trickle down effect sudah tidak diyakini banyak ahli sebagai proses terapi alauninh terhadap ketimpangan pembangunan, karena terbukti ketika terjadi pertumbuhan ekonomi yang tinggi, tingkat kemiskinan yang tinggi tetap menjadi golongan mayoritas dan masih menjadi beban bagi sistem ekonomi secara keseluruhan.

21) Nurimansyah Hašibuan, Bayang-bayang Ekonomi : Klasik Sektor Infornasi dan Pengentasan Kemiskinan, Majalah Unisia No. 21, UIl, Yogyakarta, 1994, hal. $11-24$

22) Adi Sasono, Pembinaan Sektor Informal : Koperasi Sebagai Pilihan Kelembagaan, dalam Sri Swasono (ed) Sistem Ekonomi dan Demokrasi Ekonomi, UII Press, Jakarta, 1985 hal 247 - 256 
1. Kegiatan usahá tidak terorganisir"secara baik, karena timbulnya unit usaha tidak mempergunakan fasilitas/kelembagaan yang tersedia di sektor formal

2. Pada umumnya unit usaha tidak mempunyai ijin usaha

3. Pola kegiatan usaha tidak teratur, baik dalam arti lokasi maupun jam kerja

4. Pada umumnya kebijakan pemerintah untuk membantu golongan ekonomi lemah tidak sampai ke sektor ini

5. Unit usaha mudah keluar dan masuk satu sub-sektor ke lain sub-sektor

6. Teknologi yang digunakan bersifat primitif

7. Modal dan perputaran usaha relatifkecil, sehingga skala operasi juga relatif kecil

8. pendidikan yang diperlukan untuk menjalankan usaha tidak memerlukan pendidikan formal, karena pendidikan yang diperlukan diperoleh dari pengalaman sambil kerja .

9. Pada umumnyà unit usaha termasuk golongan one-män enterprise dan kalau mengerjakan buruh berasal dari keluarga

10.Suniber dana modal usaha pada umumnya berasal dari tabungan sendiri atau lembaga keuangan yang tidak resmi

11. Hasil produksi atau jasa terutama dikonsumsi oleh golongan masyarakat kota/desa yang berpenghasilan rendah. dan kadang-kadang juga golongan menengah.

Bila karakteristik sektor informal tersebut lebih diklasifikasiuntuk keperluan komparasi guna mengetahui kekuatankelemahan sekaligus positioning sektor informal dalam ekonomi yang dualistik, maka ditemukan perbedaan karakteristik antara sektor formal dan informal yang ditunjukkan tabel berikut :23

23) Hidayat, Sektor Informal Dalam Struktur Ekonomi Indonesia, dalam Profil Indonesia 1979. LSP, Jakarta, 1980 hal. 37

\section{Tabel 3}

Pèrbedaan Karakteristik Sektor Informal dan Sektor Formal

\begin{tabular}{|c|c|c|}
\hline Karakteristik & Sektor Formal & Sektor Informal \\
\hline Modal & Relatif mudahdiperoleh & Sukar diperoleh \\
\hline - Teknologi & Padat modal & Padat karya \\
\hline Organisasi & Birokrasi : & Keluarga \\
\hline Kredit 7. & Dari lembaga keuangan resmi & LK tidak resmi \\
\hline Serikat Buruh & Sangat berperan & Tidak berperan \\
\hline Bantuan Pemerintah & Penting untuk kelangsungan hidup & Tidak ada \\
\hline Hubungan dengan desa & $\begin{array}{l}\text { One-way traffic untuk kepentingan } \\
\text { sektor formal }\end{array}$ & Saling menguntungkan \\
\hline Sifat Wiraswasta & Sangat pada proteksi dan impor & Berdikari \\
\hline Persediaan barang & Jumlah besar dan kualitas baik & Jumlah kecil dan kualitas \\
\hline$:$ & & ah-ubah : \\
\hline Hubungan Kerja & Berdasarkan kontrak kerja: ? , & Asas saling percaya \\
\hline
\end{tabular}


Dari komparasi tersebut didapati bahwa sektor informal merupakan sektor yang tidak bisa dianggap sekedar black economy, karena dia mempunyai karakteristik kemandirian yang tinggi dan, cukup resisten walau tanpa proteksi dan yang lebih urgen lagi menjadi karup pengaman gelombang tenaga kerja yang kian melimpah.

Kesulitan pemerintah dan birokrasi untukmenggarapdanmembangun ekonomi informal secara tuntas sering terbentur oleh beberapa kendala : ${ }^{24}$

1. Kurangnya pengetahuan deskriptif maupun analitis mengenai jenis, unit dan luas kegiatan ekonomi informal ini

2. Tidak mempunyai kekuasaan birokrat untuk mencapai daerah pedesaan, pinggiran kota, dan pemukinan kumuh yang kebanyakan digeluti oleh pelaku ekonomi informal ini

3. Kurangnya tenaga yang manípu mengetahui dengan baik seluk beluk ekonomi informal ini

4. Diterapkan peraturan dan prosedurkaku serta tidak luwes dalam sektor informal

5. Terdapat suatú kenyataan yang sederhana, yaitu tidak adanya sumber dana yang dapat mencakup permintaan sektor tradisional yang luas ini.

Untuk itu ada beberapa hal yang perlu kiranya mendapat perhatian berkaitan dengan keberadaan sektor informal: Pertama, masalah batasan sektor informal agar masalah dan sasaran dapat lebih mengena. Kedua, upaya yang mencoba untuk mempercepat pengubahan cara pandang danlebihcepat pula adalahmencari upaya-upaya yang lebih cocok untuk membina dan mengembangkan sektor informal.
Hal Ketiga, adalah aspek pendekatan metodologis. Olch karena bagi perencana dan juga pelaksana pembangunan sektor ini masih merupakan sektor remang-remang (grey sekror) yang tidak perlu diperhatikan. Hal ini mungkin karena hanya melihat nilai tambah dan produktivitas yang relatif rendah, tetapi melupakan aspek lain yang relatif lebih penting, yakni penyerapan tenaga kerja dan pemanfaatan sumberdaya lokal ataupun domestik untuk kebutuhan domestik lokal, domestik dan juga ekspor.

Hal Keempat, adalah peranan infra struktur sosial ekonomi. Dalam membina dan mengembangkan sektor informal, dalam banyak hal program sosial tampaknya cenderung lebih diprioritaskan daripada program, ekonomi. Prioritas ini sering dibalik, sehingga menimbulkan ketidaksiapan kelompok sasaran. Program ekonomi bukannya tidak penting, tetapi untuk suksesnya program ekonomi, program sosial sering menjadi hambatan pada tahap awal.

Hal Kelima, adalah aspek kelembagaan yang menyangkut mikro dan makro. Pengertian kelembagaan bukan hanya fisik, tetapi yang tidak kurang pentingnya adalah kelembagaan yang bersifat fisik, nilai-nilai kehidupan seperti tradisi dan perilaku individu dan kelompok yang mendukung tercapainya tujuan pembangunan yang membaku dalam berinteraksi ${ }^{25}$

24). Didik J. Rachbini op. cit hal 13

25) Nurimansyah Hasibuan, Loc cit 


\section{Penutup}

Sudah sejak pelaksanaan Repelita II disadari bahwa mengenai sasaran pemerataan dan keadilan jauh lebih sulit ketimbang sasaran stabilitas dan pertumbuhan ekonomi. Sebabnya adalah karena stabilitas ekonomi bisa dicapai melalui suatu kebijakan terpusat (sentralistik) dan pertumbuhan ekónomi yang cepat bisa dicapai melalui strategi ekonomi yang benar-benar bertumpu pada golongan ekonomi kuat (betting on the strong).

Sebaliknya sasaran pemerataan dan keadilan memerlukan syarat lain yang sulit dipenuhi tetapi tak bisa ditawar lagi yaitu partisipasi dari semua kelompok ekonomi khususnya kelompokekonomi rakyat yang lemah. Pemerataan dan keadilan sulit menjangkau kelompok ekonomi lemah karena mereka tidak mempunyai akses -walau dalam batas minimal .- terutama modal dan teknologi untuk berpartisipasi dalam aneka kegiatan yang sangat kompetitif dan sekaligus monopolistikoligopolistik. Untuk itu langkah-langkah konkrit perlu dilakukan agar pemerataan dan keadilan bisa terwujud melalui strategi kebijakan ekonomi yang langsung melibatkan mereka dalam kegiatan ekonomi.

Persoalan sektor informal selama ini lebih banyak dilihat bukan karena masalah internal dari sektor tersebut, melainkan karena posisi struktural yang kurang menguntungkan sehingga sektor ini kurang berkembang. Dengan demikian pemecahannya tidak bisa dilakukan hanya membenahi struktur intemal dari sektor informal, melainkan harus terintegrasi dengan pemecahan masalah struktur luar secara makro.

Persoalan lain pada sisi pemerintahan daerah juga harus diselesaikan, karena pada level birokrasi itulah persoalan ekonomi informal mengalami kemacetan akibat dari pola kebijakan langsung (direct approach) karena dianggap mengganggu kehidupan ekonomi yang formal. Seharusnya dampak negatif yang ditimbulkan harus diatasi lewat pranta dan kelompok-kelompok yangsudah melembaga dikalangan mereka sendiri, sehingga kebijaksanaan pemerintah bersífat tidak langsung (indirect strategy) yang bersifatmenstimulasi mereka yang bergerak di sektor informal untuk berkembang lebih jauh dan pindah ke sekıor yang lebih baik. Dua hal terpenting yang harus dipertimbangkan dalam membina sektor informal adalah: unsur kewirausahaan dan semangat mereka untuk mengelak dari ketidakberdayaan yang diciptakan olch sistem yang sempit serta peluang partisipasi yang terbatas.

\section{Daftar Bacaan}

Adi Sasono, Pembinaan Sektor Informal: Koperasi Sebagai Pilihan, dalam Sri Edi Swasono (editor), Sistem Ekonomi dan Demokrasi Ekonomi, UI Press, Jakarta, 1985.

Arif Hartono, Gugatan Kaum Burwh terhadap Ketimpangan dalam Industri, Jurnal Ekonomi, TH I Vol.3-Juni 1994, FE UII, Yogyakarta, 1994.

Asep Djaja Saefullah. Mobilitas Penduduk dan Perubahan di Pedesaan, Prisma No. 7 1994, Jakarta 1994, hal.35-47.

Bruce Glasiburner dan Adityawan Chandra, Teori dan Kebijakan Ekonomi Makro, LP3ES, Jakarta, 1979.

DidikJ.Rachbini, Ekonomi Informal Perkotaan, LP3ES, Jaḳarta, 1994. 
Dorojatun Kuncorojatki (editor), Kemiskinan di Indonesia, Yayasan Obor Indonesia, Jakarta 1986.

Edy Suandi Hamid, Penanggulangan Kemiskinan di Indonesia (Catatan ProgramIDT danKemiskinan Kota), Unisia, No.21-1994, UII. Yogyakarta.

Hidayat, Sektor Informal dalam Struktur Ekonomi Indonesia, LSP, Jakarta, 1980.

'Ian Roxborough, Teori-teori Keterbelakangan,' LP3ES, 1990.

J.H.Boeke, Memperkenalkan Teori Ekonomi Ganda, dalam Sajogyo, (penyunting), Bunga Rampai Perekonomian Desa, Yayasan Obor Indonesia dan Yayasan Agro Ekonomika, 1982.

Michael Todaro,Pembangunan Ekonomi Dunia Ketiga, Erlangga, Jakarta.

Mubyarto, Dari Program Stabilisasi sampai Kebijaksanaan Berkelanjutan, Makalah Seminar Nasional Analisis Antarera Pembangunan Ekónomi Indonesia, FE UII-ICMI Orwil DIY. Yogyakarta 2526 Maret 1994.
Kebijaksanaan Penanggulangan

- Kemiskinan, Makalah Seminar Peranan Iptek dalam rangka Pengentasan Kemiskinan, Yogyakarta, 27 Nopember 1993.

Murdjaman dkk, Aspek Pembinaan Sektor Informal dalam Kaitannya dengan Pemerataan Pendapatan di DKI Jakarta '88, Laporan Penelitian, FE Universitas Pancasila, Jakarta, 1988.

Nurimansyah Hasibuan, Bayang-bayaing Ekonomi Klasik: Sektor Informal dan PengentasanKemiskinan,UnisiaNo.21,

J UII, Yogyakarta, 1994.

Parsudi Suparlan (editor), Kemiskinan di Perkotaan. Yayasan Obor Indonesia, Jakarta, 1993.

Sritua Arief dan Adi Sasono, Indonesia: Ketergantungan dan Keterbelakangan, LSP, Jakarta. 1981:

Sumitro Djojohadikusumo, Perdagangan dan Industri dalam Pembangunan. LP3ES, Jakarta, 1987.

Yeremias T. Kebän, Stúdi Niat Bermigrasi di Tiga Kota, Prisma No. 7, 1994. 